\title{
連続培養培地中における硫酸塩還元菌の代謝と 炭素鋼の腐食挙動
}

\author{
馬場文雄*, 鈴木紹夫*, 瀬尾眞浩** \\ * 味の素株式会社生産技術研究所 \\ ** 北海道大学大学院工学研究科
}

\begin{abstract}
The Metabolism of Sulfate-reducing Bacteria and Corrosion Behavior of Carbon Steel in the Continuous Culturing Medium
\end{abstract}

\author{
Fumio Baba*, Tsuguo Suzuki* and Masahiro Seo** \\ * Technology \& Engineering Laboratories, Ajinomoto Co., Inc. \\ ** Graduate School of Engineering, Hokkaido University
}

\begin{abstract}
Carbon steel was exposed for long time to an inoculation continuous culturing medium of sulfate-reducing bacteria (SRB). The feed rate of medium was $10 \mathrm{~cm}^{3} \mathrm{hr}^{-1}$, and the concentaration of $\mathrm{Fe}^{2+}$ of medium was kept to $0.01 \mathrm{~mol} \mathrm{~kg}^{-1}$. The corrosion behavior and metabolism of sulfate-reducing bacteria (SRB) were investigated by measuring weight change of the specimens and by using a phase-difference microscope, hydrogen sulfide gas detector, and measuring the amount of ferrous sulfide in the medium. The number of SRB was above $10^{10} \mathrm{cell} / \mathrm{cm}^{3}$ after the culture of 50 days. SRB evolved a significant amount of hydrogen sulfide and ferrous sulfide after the culture above 2 days. In the period of after the culture of 50 days, the medium contained 2 types of SRB with different shapes. One was rod like shape and the other was comma like shape. In this period, $\mathrm{pH}$ of medium was kept almost 7 without any $\mathrm{pH}$ ajusting. The weight of deposited film on the specimen increased linearly with culturing time, whereas the weight of the specimen substrate due to corrosion decreased linearly with culturing time. The corrosion rate in continuous culturing medium was larger by 7 times than that in batch culture.
\end{abstract}

Key words : metabolism, sulfate-reducing bacteria, SRB, ferrous ions, Micro biological Influenced Corrosion (MIC), FeS, carbon steel, continuous culture

\section{1. 緒言}

淡水中，特に有機物を多量に含む排水の河水口など は，種々の菌体が繁殖を行い，多様な生態系を形成して いることが知られている ${ }^{1)}$ 。溶存酸素が高い場合, 好気 性菌が繁殖し, 溶存酸素が低い場合, 硫酸塩還元菌を始 めとする嫌気性菌の繁殖が盛んとなる。同じ淡水中で あっても，場所や条件によって菌体の繁殖の状態や種類 が異なり，多様な菌体が相互に影響しあいながら生息し ている。古くから，このような菌体の生息が金属の腐食 に影響を与えているのではないかと疑われる事例が多く

* 一210 川崎市川崎区鈴木町 1-1（1-1， Suzuki-cho， Kawasaki-ku, Kawasaki, 210 Japan)

** T060 札幌市北区北 13 条西 8 丁目 (Kita-13, Nishi-8, Kita-ku, Sapporo, 060 Japan)

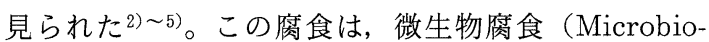
logical Influenced Corrosion : MIC) と総称され, 腐 食形態や金属の種類が多様であるため, これまで多くの

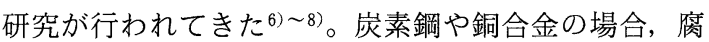
食を促進させる菌体のひとつに硫酸塩還元菌があげられ $3^{9 \sim 11)}$ 。この菌体は, 活性な状態において硫化水素を 生成し, 金属の腐食を促進させる。腐食促進のメカニズ 么は不明な点が多く, 実験室での再現が困難な場合が多 い。菌体の活性は, 水温, 栄養条件, 嫌気状態, 溶液中 の特定の金属イオンの存在などによって支配される。菌 体が活性を維持し続けて硫化水素を継続的に生じる環境 を見いだすことは，防止法としての環境制御につながる ため重要である。実際の河水の分析值結果によれ ば'2),13)，淡水中の硫化水素の量は必ずしも多くない。 
しかし，川底など部分的に硫化物が多い場合がある ${ }^{14) 。 ~}$ このことは, 硫酸塩還元菌の繁殖が局部的で複雑である ことを伺わせる。休眠状態で生息していても，ある時期 に急激に繁殖し活性が高くなる場合があるかもしれな い。さびこぶや金属表面の付着物下に生息し，活性を高 める時期を㸚らっている場合もあるであろう。付着物下 の菌体を薬剤で完全に死滅させるのは, 薬剤が付着物下 まで完全に入り込むのが困難なため必ずしも有効ではな い。微生物腐食を拔本的に防止するためには，菌体の代 謝と腐食とのかかわりを詳細に検討する必要がある。著 者らは, 硫酸塩還元菌の腐食を防止するための基礎研究 として，炭素鋼表面近傍に多量に存在すると考えられる $\mathrm{Fe}^{2+}$ 之菌体の代謝および炭素鋼の腐食の関係を, バッ

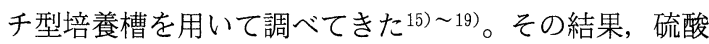
塩還元菌の代謝によって生成する硫化鉄量は, 出発培地 中に含まれる $\mathrm{Fe}^{2+}$ 濃度に依存し， $\mathrm{Fe}^{2+}$ 濃度 $1.0 \times 10^{-2}$ $\mathrm{mol} \mathrm{kg}{ }^{-1}$ で最大となることを明らかとした。この場合 の炭素鋼の腐食は最も大きくなる。腐食が促進するため には，4 週間以上の浸漬が必要となる。一旦この環境が 作られれば, 菌体が死滅しても腐食は促進していく。し かし,これまでの研究はバッチ型培養槽を用いているた め, 菌体の活性は, 培養開始から数日で栄養分の低下や $\mathrm{pH}$ の上昇によって低下した。そこで本研究では, $\mathrm{Fe}^{2+}$ 濃度 $1.0 \times 10^{-2} \mathrm{~mol} \mathrm{~kg}^{-1}$ 含む培地を連続的に供給する とともに，同じ速度で引き抜いて，50日間培養を続け た。その場合の, 菌体の代謝及び炭素鋼の腐食挙動を観 察したので報告する。

\section{2. 実験方法}

\section{1 培養方法}

実験に供した菌体は, 既報18) 之同様, 大阪発酵研究所 から入手した硫酸塩還元菌（Desulfovibrio desulfuricans : IFO No.13699) で, 液体培地で嫌気的に数回植 えついだものを使用した。連続培養用の供給培地は $\mathrm{Fe}^{2+} 1.0 \times 10^{-2} \mathrm{~mol} \mathrm{~kg}^{-1}$ 含むもので, 培地の調製方 法は既報15) 199に示す通りである。培地の組成を Table 1 に示す。試薬はすべて特級試薬を用いた。この培地を ガラス製の連続培養槽に $800 \mathrm{~cm}^{3}$ 投入し, 超高純度 （99.998\%以上）の窒素ガスを $100 \mathrm{~cm}^{3} \mathrm{~min}^{-1}$ の流速で 吹き込みながら, 菌体培養液を $0.5 \mathrm{~cm}^{3}$ 接種して, $37^{\circ} \mathrm{C}$ で 50 日間連続培養した。培地は $10 \mathrm{~cm}^{3} \mathrm{hr}^{-1}$ の速 度で培地槽から連続培養槽に供給され, 同じ速度で廃液 槽に引き抜かれた。この連続培養槽に炭素鋼を浸漬し, 種々の解析に供した。

\section{2 菌体 観 察}

菌体の形状および活動状態の観察は既報18)の通り，位 相差顕微鏡（(株)ニコン製 $\mathrm{X} 2 \mathrm{~F}-\mathrm{Ph} ）$ を用いて油浸法
Table 1 Chemical composition of continuous culturing medium ( $\mathrm{pH}$ 7.0).

\begin{tabular}{ll}
\hline $50 \%$ Na-lactate & $10 \mathrm{~cm}^{3}$ \\
East-extract & $0.4 \mathrm{~g}$ \\
Pepton & $3.0 \mathrm{~g}$ \\
$\mathrm{KH}_{2} \mathrm{PO}_{4}$ & $0.4 \mathrm{~g}$ \\
$\mathrm{Na}_{2} \mathrm{SO}_{4}$ & $3.0 \mathrm{~g}$ \\
$\mathrm{MgSO}_{4} \cdot 7 \mathrm{H}_{2} \mathrm{O}$ & $0.6 \mathrm{~g}$ \\
$\mathrm{FeSO}_{4} \cdot 7 \mathrm{H}_{2} \mathrm{O}$ & $2.77 \mathrm{~g}$ \\
Distilled water & $1 \mathrm{dm}^{3}$ \\
\hline
\end{tabular}

で行った。菌体数は希釈法によって最確数 (Most Probable Number) $/ \mathrm{cm}^{3}$ で求めた。

\section{3 硫化水素濃度の測定}

培地から発生する硫化水素ガス濃度の測定は, 検出限 度 $0.1 \mathrm{ppm}$ の定電位式硫化水素検出器（(株)ガステッ ク製 HS-2B）を用いて行った。なお，硫化水素ガス発 生速度は流出ガス中の硫化水素濃度と流量から求めた。 培地中の硫化水素濃度および生成する硫化鉄量の測定は 既報17)の通り検知管法と 0 -フェナントロリン法によっ た。

\section{4 培地の $\mathrm{pH}$ 変化}

培地中の $\mathrm{pH}$ は一定時間ごとに培地を $20 \mathrm{~cm}^{3}$ サンプ リングし小型ビーカーに入れ，これに東亜電波工業 (株)製 $\mathrm{pH}$ 電極を浸漬して測定した。

\section{5 試験片の腐食状態の解析}

0.06C, 0.002Si，0.30Mn，0.019P，0.010S の化学 成分（重量\%) を持つ一般構造用圧延鋼（SS-400）か ら, $12 \mathrm{~mm} \times 30 \mathrm{~mm} \times 3 \mathrm{~mm}^{\mathrm{t}}$ の矩形状に試験片を切り 出した。この炭素鋼（SS-400）試験片を培養槽に水平 方向に浸漬し, 一定期間ごとに試験片を取り出して, 重 量減量及び皮膜重量の測定を行った。すなわち一定期間 ごとに試験片を取り出し, 試験片の初期重量を $W_{1}$, 浸 漬終了後の試験片の重量を $W_{2}$, 皮膜除去後の重量を $W_{3}$ として，それぞれの重量変化量 $\left(W_{1}-W_{3}\right) / A$ およ び $\left(W_{2}-W_{3}\right) / A$ を測定した。 $A$ は試験片の表面積 $\left(\mathrm{cm}^{2}\right)$ である。なお, $\left(W_{1}-W_{3}\right) / A$ は試験片下地の 腐食による重量変化に, $\left(W_{2}-W_{3}\right) / A$ は, 腐食生成物 および溶液から付着した硫化鉄なごの沈殿物による重量 変化（皮膜重量）に相当する。ここでは，腐食生成物と 沈殿物を区別せず, $\left(W_{2}-W_{3}\right) / A$ をすべて皮膜重量と して取り扱う。いずれの試験においても試験片の再浸漬 は行わなかった。試験片の皮膜は, 試験片を $30^{\circ} \mathrm{C}$ の 1 \%プロパギルアルコールを含む $10 \mathrm{wt} \% \mathrm{HCl}$ 中で $30 \mathrm{~s}$ 間 浸漬して除去した。試験装置の概略図を Fig. 1に示す。 


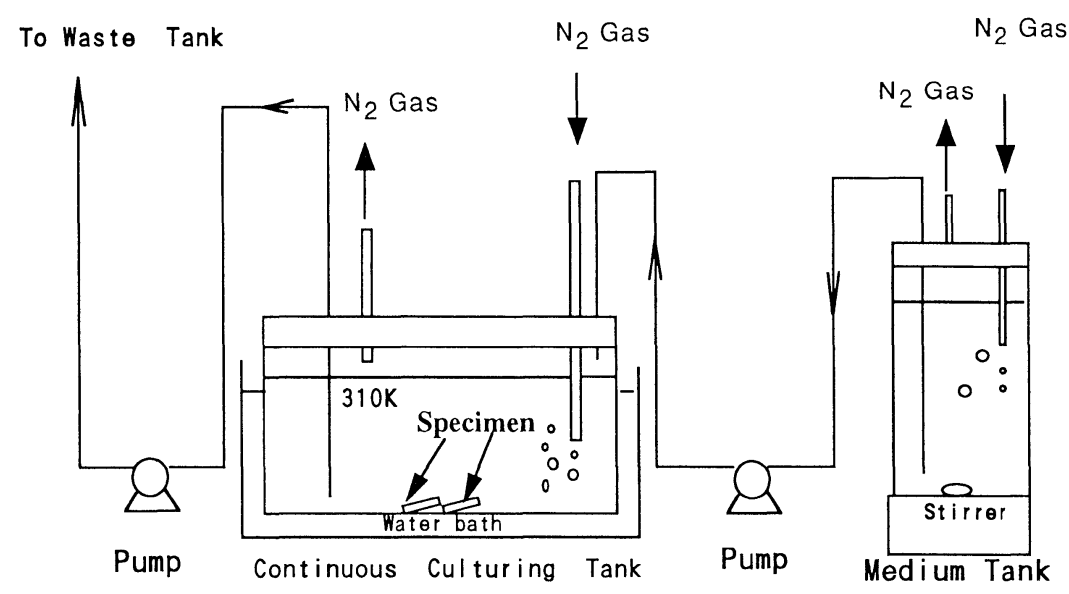

Fig. 1 Schematic diagram of corrosion cell for continuous culturing of sulfate-reducing bacteria.

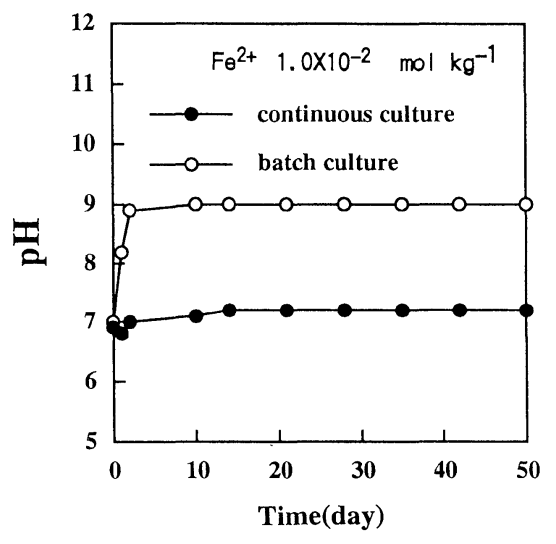

Fig. $2 \mathrm{pH}$ values of the SRB inoculation medium as a function of continuous culturing time.

\section{3. 実験結果および考察}

\section{1 培地の液性変化}

連続培養槽中の培地の $\mathrm{pH}$ の経時変化, 菌体数, およ び硫化水素ガス発生速度を Fig. 2 から Fig. 4 に示す。 また，硫化鉄の生成量の経時変化および培養期間を通じ て生成した全 $\mathrm{FeS}$ 量を Fig. 5 に示す。硫化鉄はさまざ まな化学組成が報告されているが20), 21), ここでは FeS として取り扱う22), 23)。培養全般を通じて培地の $\mathrm{pH}$ は 7.0 付近を推移した。バッチ培養時のような $\mathrm{pH}$ の上 昇 ${ }^{18)}$ は培養開始から 50 日後も認められなかった。培養 槽中の菌体数は, 培養全般を通じて $10^{10} \mathrm{cell} \mathrm{cm}^{-3}$ 以上 の高い值を維持した。従来のバッチ培養では, 菌体数は 培養 40 日間で $10^{6} \mathrm{cell}^{\mathrm{cm}} \mathrm{cm}^{-3}$ まで低下することから, 連 続培養の方がバッチ培養よりも菌体の生育に有利である ことがわかる。連続培養において硫化水素ガスの発生 は, 培養 2 日で $8 \times 10^{-6} \mathrm{~mol} \mathrm{~min} \mathrm{~m}^{-1}$ の定常值に達し, そ

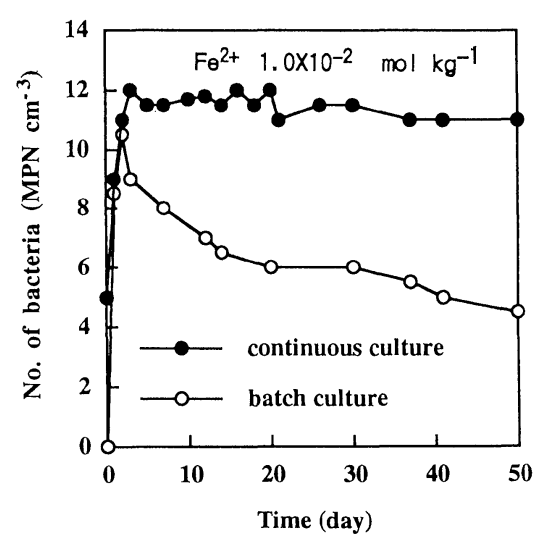

Fig. 3 The growth of sulfate-reducing bacteria in the medium as a function of continuous culturing time.

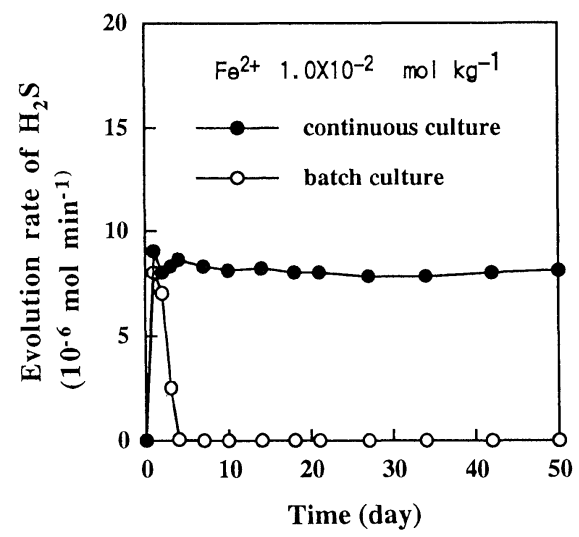

Fig. 4 The evolution rate of hydrogen sulfide gas in the medium as a function of continuous culturing time. 

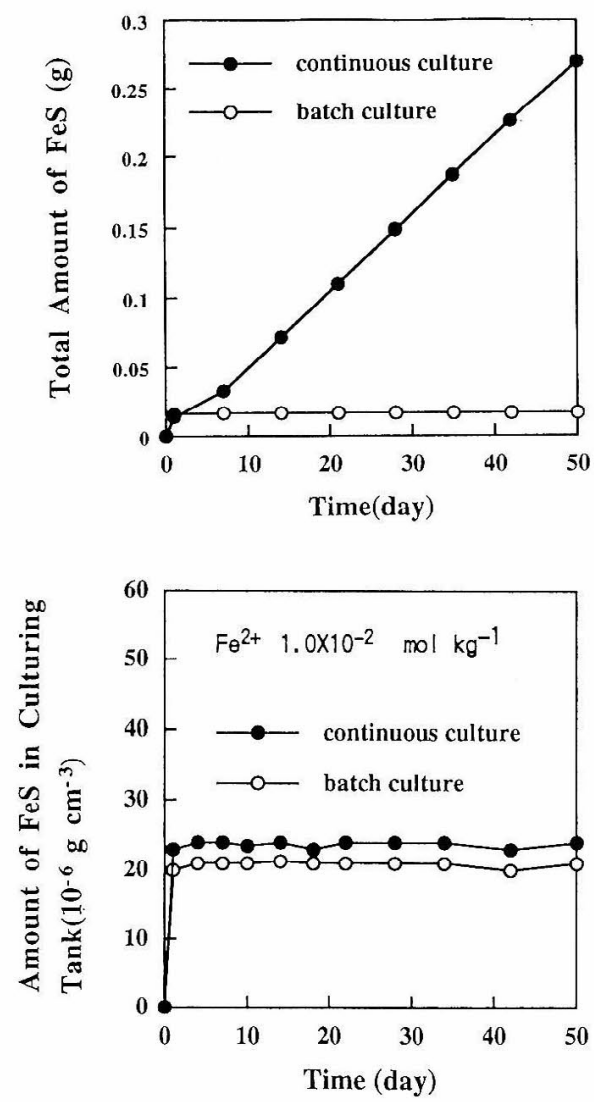

Fig. 5 Amount of FeS produced in the SRB inoculation medium as a function of continuous culturing time.

の後も同様の速度で生成し続けた。検知管法により培地 巾に $\mathrm{H}_{2} \mathrm{~S}$ の存在は検出限度内で確認されなかった。一 方, FeS の生成は, 培養 2 日で定常状態に達した後, $23 \times 10^{-6} \mathrm{~g} \mathrm{~cm}^{-3} \mathrm{day}^{-1}$ の速度で生成し続けた。連続培 養 50 日間で生成した FeS の総量は $0.27 \mathrm{~g}$ である。 バッチ培養の場合, 硫化水素ガスおよび FeSの生成は 培養 2 日で停止したことから，連続培養の場合の方が菌 体の活性についても有利である。

\section{2 菌体の形状変化}

培養 4 日後および 50 日後の菌体の形状を Fig. 6 に示 す。培養開始 2 日後から培養終了まで培地中には，2 種 類の形状の菌体が存在した。第一はコンマ状の菌体で 1 個あたりの長さは $2 \mu \mathrm{m}$ から $3 \mu \mathrm{m}$ であった。激しく躍 動や乱舞を繰り返し活発に運動を行っていた。第二は棒 状の菌体で 1 個あたりの長さは 3〜 $4 \mu \mathrm{m}$ であった。運 動は軽敏な振り子状であった。顕微鏡観察から，コンマ 状の菌体数が非常に多く, 棒状の菌体数を圧倒している ことがわかった。既報 ${ }^{18)} に$ 述べたようなコロイド状物質 に単体で密着する $1 \mu \mathrm{m}$ 程度の楕门形の菌体群の存在は
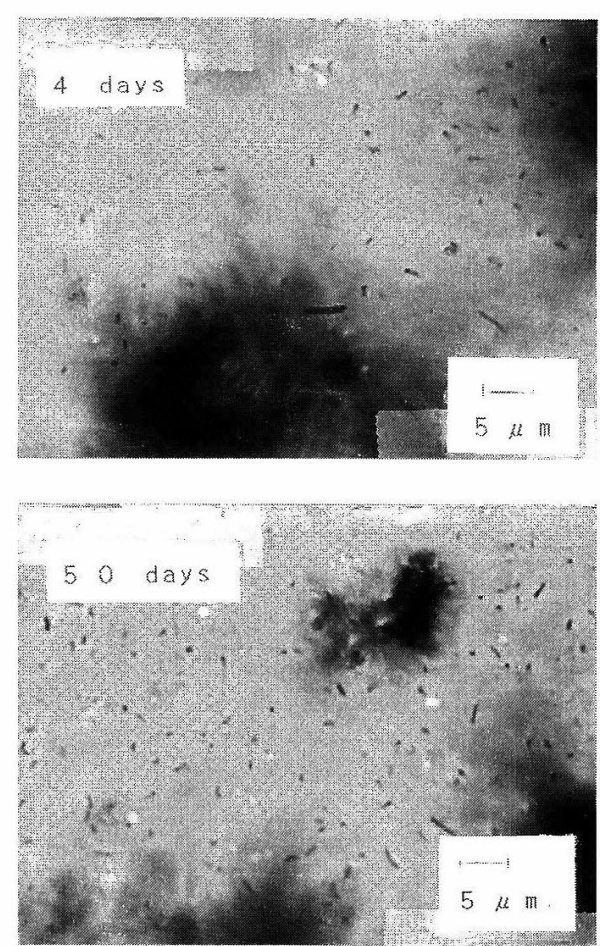

Fig. 6 The shape of sulfate - reducing bacteria in the continuous culturing medium after culture of 4 days and 50 days.

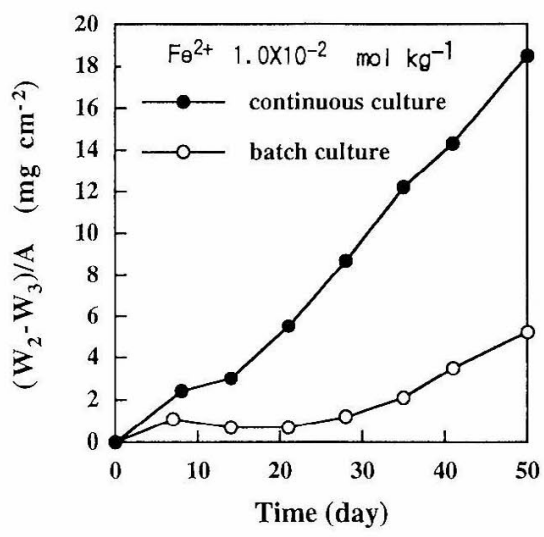

Fig. 7 Weight gain, $\left(W_{2}-W_{3}\right) / A$, of the specimens immersed in the SRB inoculation medium as a function of continuous culturing time and of batch culturing time.

培地の黒変によって観察出来なかった。

\section{3 腐食試験結果}

炭素鋼試験片を培養槽の底に浸漬した場合の皮膜重量 $\left(W_{2}-W_{3}\right) / A$ の経時変化を Fig. 7 に示す。試験片上の 皮膜重量は, 培養開始から顕著に増加し, 時間の経過と 


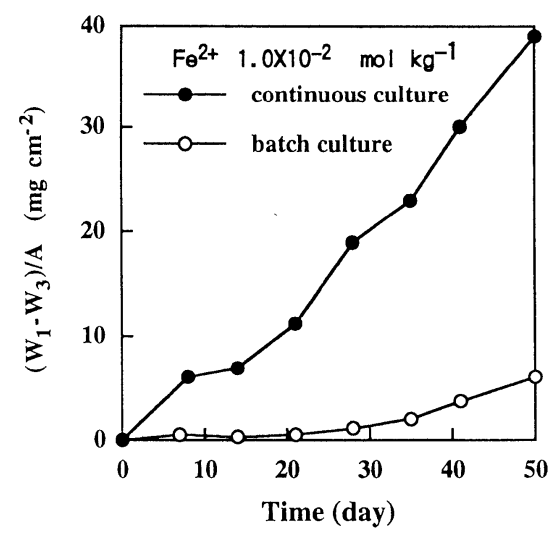

Fig. 8 Weight loss, $\left(W_{1}-W_{3}\right) / A$, of the specimens immersed in the SRB inoculation medium as a function of continuous culturing time and of batch culturing time.

ともに直線的に増加した。皮膜の性質は, 試験片を洗浄 しても簡単には流れ落ちないものだった。重量減少量 $\left(W_{1}-W_{3}\right) / A$ の結果を Fig. 8 に示す。重量減少量は培 養開始から大きく, 時間の経過とともに直線的に増加し て, 培養 50 日で $40 \mathrm{mg} \mathrm{cm} \mathrm{cm}^{-2}$ に達した。これはバッチ 培養槽における腐食減少量の 7 倍近い值である。培養全 般を通じて試験片の表面に黒色の付着物が見られ，付着 物の下層に梨地状の腐食が生じていた。

\section{4. 腐食機構に関する考察}

以上の結果から, 以下の腐食のモデルを提案した。特 に硫化鉄の組成分析を行っていないので，モデルを考え る上で障害とならない範囲で硫化鉄を $\mathrm{FeS}$ として取り 扱う。まず，おもに硫酸呼吸をつかさどっている菌体の 代謝とこれにともなう環境変化について考察した。

$$
\begin{aligned}
& \mathrm{SO}_{4}{ }^{2-}+8 \mathrm{H}=\mathrm{S}^{2-}+4 \mathrm{H}_{2} \mathrm{O} \\
& \mathrm{S}^{2-}+\mathrm{H}^{+}=\mathrm{HS}^{-} \\
& \mathrm{HS}^{-}+\mathrm{Fe}^{2+}=\mathrm{FeS}+\mathrm{H}^{+} \\
& \mathrm{HS}^{-}+\mathrm{H}^{+}=\mathrm{H}_{2} \mathrm{~S}
\end{aligned}
$$

(1)式から（4)式で示される反応式24～27)において, 菌体数, 基質としての $\mathrm{Fe}^{2+}$ 量, $\mathrm{SO}_{4}{ }^{2-}$ 量, 生産物とし ての FeS 量の収支を考えると，それぞれ，

$($ 菌体濃度変化 $)=($ 菌体流入 - 菌体流出 $)+$ 菌体増殖

$$
V \frac{d X}{d \mathrm{t}}=F(0-X)+V \cdot r_{x}
$$

ここで, $X$ : 菌体数 $\left[\right.$ cell $\left.\mathrm{cm}^{-3}\right], V$ : 培地の容量 $\left[\mathrm{cm}^{3}\right], F$ : 培地の流入および流出速度 $\left[\mathrm{cm}^{3} \mathrm{hr}^{-1}\right]$, $r_{x}:$ 菌体增殖速度 [cell $\mathrm{cm}^{-3} \mathrm{hr}^{-1}$ ] である。 $($ 基質濃度变動 $)=($ 基質流入 $)-($ 基質流出 $)$

$$
\text { - (菌体による消費) }
$$

$$
-V \frac{d\left[\mathrm{SO}_{4}{ }^{2-}\right]}{d t}=F\left(\left[\mathrm{SO}_{4}{ }^{2-}\right]-\left[\mathrm{SO}_{4}{ }^{2-}\right]\right)-\frac{V \cdot r_{x}}{Y_{x / s}}
$$

ここで, $V:$ 培地の容量 $\left[\mathrm{cm}^{3}\right], F$ : 培地の流入およ び流出速度 $\left[\mathrm{cm}^{3} \mathrm{hr}^{-1}\right],\left[\mathrm{SO}_{4}{ }^{2-}\right]_{0}$ : 流入する $\mathrm{SO}_{4}{ }^{2-}$ の濃度 $\left[\mathrm{mol} \mathrm{cm}{ }^{-3}\right],\left[\mathrm{SO}_{4}{ }^{2-}\right]$ : 流出する $\mathrm{SO}_{4}{ }^{2-}$ の濃 度 $\left[\mathrm{mol} \mathrm{cm} \mathrm{cm}^{-3}\right], r_{x}$ : 菌体堌殖速度 [cell $\mathrm{cm}^{-3} \mathrm{hr}^{-1}$ ], $\mathrm{Y}_{x / s}$ : 基質消費に対する増殖収率 $[\mathrm{cell} / \mathrm{mol}$ - substrate]である。

$($ 生成物濃度変動 $)=($ 生成物流入 $)-($ 生成物流出 $)$

$$
\begin{gathered}
+(\text { 生産 }) \\
V \frac{d[F e S]}{\mathrm{dt}}=F(0-[\mathrm{FeS}])+V \cdot r_{p}
\end{gathered}
$$

ここで, $V:$ 培地の容量 $\left[\mathrm{cm}^{3}\right],[F e S]: \mathrm{FeS}$ の濃度 $\left[\mathrm{mol} \mathrm{cm} \mathrm{cm}^{-3}\right], F$ : 培地の流入および流出速度 $\left[\mathrm{cm}^{3}\right.$ $\left.\mathrm{hr}^{-1}\right], r_{p}$ : 生産物生成速度 $\left[\mathrm{mol} \mathrm{cm} \mathrm{cm}^{-3} \mathrm{hr}^{-1}\right]$ であ る。

菌体数に関して収支を取ると, 定常状態 $(d X / d t=0)$ では, (5)式から

$$
X(F / V)=r_{x}
$$

菌体增殖速度に多く用いられる Monod 式28)が成立す ると仮定すると, 菌体の増殖速度は,

$$
r x=\mu X
$$

ここで $\mu$ は比增殖速度 $\left[\mathrm{hr}^{-1}\right]$ である。

希釈率 $D$ を $F / V\left[\mathrm{hr}^{-1}\right]$ （液の平均滞留時間の逆数） とすると，(8)式および（9)式から

$$
D=\mu
$$

定常状態では，希釈率は菌体の比增殖速度に等しい。 従って, 培地の供給速度を变化させることで, 比増殖速 度を制御できる。今回の $F / D$ 值から計算すると, 菌体 の比增殖速度 $\mu$ は $0.0125 \mathrm{hr}^{-1}$ である。

次に基質濃度に関して収支を取ると, 定常状態 $\left(d\left[\mathrm{SO}_{4}{ }^{2-}\right] / d t=0\right)$ では，(6)式および（8)式から

$$
Y_{x / s}\left(\left[\mathrm{SO}_{4}{ }^{2-}\right]-\left[\mathrm{SO}_{4}{ }^{2-}\right]\right)=X
$$

定常状態における菌体数はほぼ一定であるので, 培地 中における硫酸濃度を測定出来れば，硫酸消費に対する 増殖収率 $Y_{x / s}[\mathrm{cell} / \mathrm{mol}$-substrate $]$ を求めることが出 来る。

$\mathrm{FeS}$ 濃度に関して収支を取ると, 定常状態 $(d[\mathrm{FeS}] /$ $d t=0)$ では, (7)式から

$$
F[\mathrm{FeS}]=V \cdot r_{p}
$$

$F$ に $10 \mathrm{~cm}^{3} \mathrm{hr}^{-1}, \quad[F e S]$ に $2.0 \times 10^{-7} \mathrm{~mol} \mathrm{~cm} \mathrm{~cm}^{-3}$, $V$ に $800 \mathrm{~cm}^{3}$ をそれぞれ代入すると, 生産物生成速度 $r_{p}$ は $2.5 \times 10^{-9} \mathrm{~mol} \mathrm{~cm}^{-3} \mathrm{hr}^{-1}$ となる。

ところで, $800 \mathrm{~cm}^{3}$ の培養槽中に 1 時間あたりに生成 する $\mathrm{FeS}$ の量を計算すると, $2.0 \times 10^{-6} \mathrm{~mol}$ である。定 常状態において培地中に存在する $\mathrm{FeS}$ 量は $2.1 \times 10^{-4}$ 
mol で 1 時間あたりの生成量の 100 倍近い。また, 培 地の $\mathrm{pH}$ はほぼ一定で, 至適な 7.0 付近を維持し続けた ため, 菌体数は 50 日後も $10^{10} \mathrm{cell} \mathrm{cm}^{-3}$ 以上で存在し た。菌体の活性が高かったことから, 安定して硫化水素 および硫化鉄を生成し続けたものと考えられる。Fig. 6 において 2 種類の形状の菌体の存在が確認されたこと から, 硫酸呼吸を活発に行うコンマ状の菌体とそれほど 活発ではない棒状の菌体が, 定常的に培地中で生息して

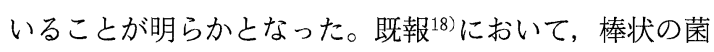
体は接種初期において存在し, コンマ状の菌体は培養が 進行した状態で存在することが確認されている。今回の 場合も, 培養槽中に比較的長時間滞在していた菌体がコ ンマ状の菌体となって硫化水素を発生し, 新たに生じた 比較的若い菌体が棒状となったのであろう。培地が連続 的に供給される定常状態においては両者の存在比は一定 となるはずである。これは Fig. 6 において培養 4 日後 と50日後とで菌体の状態が大差ない事実から支持され る。

一方, Fig. 8 において, 炭素鋼下地の重量は直線的 に減少した。バッチ培養の場合に下地重量が 4 週間経過 してから減少し始めたのに対し, 連続培養の場合は培養 初期から一定の割合で腐食が進行した。Fig. 7 の皮膜 の重量は時間の経過とともに直線的に増加して, 下地の 重量減少量と同様の傾向にあることを示している。下地 の重量減少と皮膜の重量増加との間に強い相関が認めら れたことから，連続供給培養においても，既報 ${ }^{19)} に$ 示す ように，培地中の FeS が炭素鋼表面に付着する過程を ともないながら腐食が進行する機構が示唆される。今回 の場合, 培養初期から直線的な皮膜の重量増加および下 地の重量減少が生じた。バッチ培養の場合, 培養開始か ら数日で菌体による硫化水素および FeS の生成が停止 した。炭素鋼表面への皮膜の付着は, 培地中に生成した $\mathrm{FeS}$ が沈殿物として沈降し,これが時間の経過ととも に炭素鋼表面を覆い, 次第に緻密な皮膜に变質したため と考えられる。それと同時に炭素鋼自身の腐食が進行し 始め, 腐食生成物として $\mathrm{Fe}(\mathrm{OH})_{2}$ あるいは $\mathrm{Fe}_{3} \mathrm{O}_{4}$ が生 成する。一方, 今回の連続培養の場合は, (1)式および (2)式の反応が継続的に生じ，その結果として（3)式の 反応も継続的に進行する。培地中の $\mathrm{FeS}$ 量は, 定常状 態では一定であり, 見かけ上はバッチ培養の量と大差な い。しかし, 連続培養の場合, 培地中に $\mathrm{HS}^{-}$が常に存 在している関係から, 炭素鋼表面から溶けだす $\mathrm{Fe}^{2+}$ が 炭素鋼の表面近傍で FeS に変化しやすいと推測される。 この場合, FeS は炭素鋼表面に付着しやすいと考えら れる。同時に炭素鋼自身の腐食が進行し始め, 腐食生成 物として $\mathrm{Fe}(\mathrm{OH})_{2}$ あるいは $\mathrm{Fe}_{3} \mathrm{O}_{4}$ が生成する。容易に 付着した FeS は培養のごく初期においては, 水和して
いるため電気伝導性にそしいであろう。しかし，時間経 過とともに脱水が進行し, 緻密な皮膜に変わるため, 電 気伝導性を有するものと考えられる。従って, 緻密な $\mathrm{FeS}$ の部分がカソードとなり, 還元反応 $\left(2 \mathrm{H}_{2} \mathrm{O}+2 \mathrm{e}\right.$ $\longrightarrow \mathrm{H}_{2}+2 \mathrm{OH}^{-}$あるいは $\left.\frac{1}{2} \mathrm{O}_{2}+2 \mathrm{H}^{+}+2 \mathrm{e} \longrightarrow \mathrm{H}_{2} \mathrm{O}\right)$ を 容易に起こすであろう。また，この還元反応がアノード 部の鉄の酸化反応 $\left(\mathrm{Fe}+2 \mathrm{OH}^{-} \rightarrow \mathrm{Fe}(\mathrm{OH})_{2}+2 \mathrm{e}\right)$ と カップルして腐食を促進することが予想される。今後, 連続培養における炭素鋼表面の皮膜の組成解析, 皮膜形 成の機構, および炭素鋼表面でのカソード反応・アノ一 ド反応を調べることによって，炭素鋼表面における腐食 機構をさらに詳細に検討する必要がある。

\section{5. 結言}

所定の濃度に調整した培地を $10 \mathrm{~cm}^{3} \mathrm{hr}^{-1}$ の速度で連 続的に供給しながら同じ速度で引き抜いて硫酸塩還元菌 の培養を行った。この培地中に炭素鋼を50日間浸漬し て炭素鋼の腐食挙動を調べた。その結果, 次のような結 論を得た。

1）培養 50 日後の菌体数は $10^{10}$ 以上を維持し, 菌体 は培養終了まで安定して $\mathrm{H}_{2} \mathrm{~S}$ および FeS を生成した。 菌体の代謝にかかわる物質収支から, 菌体の比増殖速度 $\mu$ は $0.0125 \mathrm{hr}^{-1}$, 生産物生成速度 $r_{p}$ は $2.5 \times 10^{-9} \mathrm{~mol}$ $\mathrm{cm}^{-3} \mathrm{hr}^{-1}$ と計算された。

2）培養 4 日後から 50 日後まで培地中には 2 種類の 形状の菌体が存在した。第一はコンマ状の菌体で 1 個あ たりの長さは $2 \mu \mathrm{m}$ から $3 \mu \mathrm{m}$ であった。激しく躍動や 乱舞を繰り返し活発に運動を行っていた。第二は棒状の 菌体で 1 個あたりの長さは $3 \sim 4 \mu \mathrm{m}$ であった。運動は 軽敏な振り子状であった。顕微鏡観察から, コンマ状の 菌体数が非常に多く, 棒状の菌体数を圧倒していること がわかった。

3）培養全般を通じて炭素鋼表面に黒色の付着物が見 られ, 付着物の下層に梨地状の腐食が生じていた。付着 物の性質は, 試験片を洗浄しても簡単には流れ落ちない ものだった。炭素鋼の皮膜の重量増加および下地の重量 減少は, 培養開始から顕著であり, 時間の経過とともに 直線的に変化した。下地の重量減少量は培養 50 日で 40 $\mathrm{mg} \mathrm{cm}-2$ に達した。これはバッチ培養槽における腐食 減少量の 7 倍近い值である。今回の結果から, 連続培養 においても既報19)に示したカソードとして有効に働く $\mathrm{FeS}$ の皮膜の形成と, これによる腐食の進行の機構が 成立することが示唆された。

(Manuscript received April 23, 1997 ; in final form May 26, 1997) 


\section{参 考 文 献}

1）稲森悠平：用水之廃水，28，116（1986）.

2) R. A. King, J. D. A. Miller and D. S. Wakerley : Br. Corros. J., 8, 89 (1973).

3. C. K. Dittmer, R. A. King, and J. D. A. Miller : Br, Corros. J., 10, 47 (1975).

4) J. Horvath, M. Novak : Corros. Sci., 4, 159 (1965).

5）下平三郎：防蝕技術，22，1（1973）.

6 ）井上真由美：防蝕技術，16，453（1967）.

7 ）天谷 尚, 幸 英昭：日本金属学会誌， 58，775 (1994).

8 ）岡村 潔, 古山幸男, 梶山文夫 : 「第 39 回腐食 防食討論会講演集」, p.143（1992）.

9 ) C. K. Dittmer, R. A. King, and J. D. A. Miller : Br. Corros. J., 10, 47 (1975).

10）佐々木英次, 中原東郎, 神田幸雄, 大野一夫, 栂 野秀夫：防食技術，26，77（1977）。

11）佐々木英次, 中原東郎, 神田幸雄, 大野一夫, 栂 野秀夫：防食技術，26，125（1977）.

12）島田春夫, 三井田万穹, 武井格道 : 防蝕技術, 18, 148 (1969).

13）多賀信夫編 : 「海洋学講座 $11 」$, p. 197 , 東京大 学出版会 (1974).

14）海野武人，戸村寿一：中川防蝕技報，8，1 (1994)

15）馬場文雄, 鈴木紹夫, 瀬尾䢐浩 : 「第 41 回腐食 防食討論会講演集」, p.337（1994）.
16）馬場文雄，鈴木紹夫，瀬尾眞浩：「3 協会研究発 表会北海道支部講演集（電気化学協会，腐食防食 協会，表面技術協会)」, p.28（1995）.

17）馬場文雄, 鈴木紹夫, 瀬尾眞浩：材料と環境, 44, 606 (1995).

18）馬場文雄，鈴木紹夫，瀬尾眞浩：材料と環境, 45, 588 (1996).

19）馬場文雄，鈴木紹夫，瀬尾眞浩：材料と環境, 45, 595 (1996)

20) J. Horvath, M. Novak : Corros. Sci., 4, 159 (1965).

21）小林豊治，藤井哲雄，伊藤伍郎：金属材料技術研 究報告. 12, 418 (1969).

22) S. W. Borenstein : Microbiologically influenced corrosion handbook”, p.38, Industrial Press Inc. (1994).

23) H. H. Uhlig 著, 岡本 剛監修, 松田誠吾, 松 島㛜共訳 : 腐食反応とその制御 (第 2 版)，p. 90 , 産業図書（1974）

24）橋本 奨: 用水亡廃水, 31, 19 (1989).

25) S. W. Borenstein : Microbiologically influenced corrosion handbook”, p.23, Industrial Press Inc. (1994).

26）村田朋美：「腐食防食 '85 講演集」, p.143 (1985).

27）笠原 明，梶山文夫，岡村 潔：材料と環境, 43, 587 (1994)

28）川瀬義矩 : 「生物反応工学の基礎」, p.48, 化学工 業社（1993）。 